WEST-ÖSTLICHE BEGEGNUNG 


Tafel I

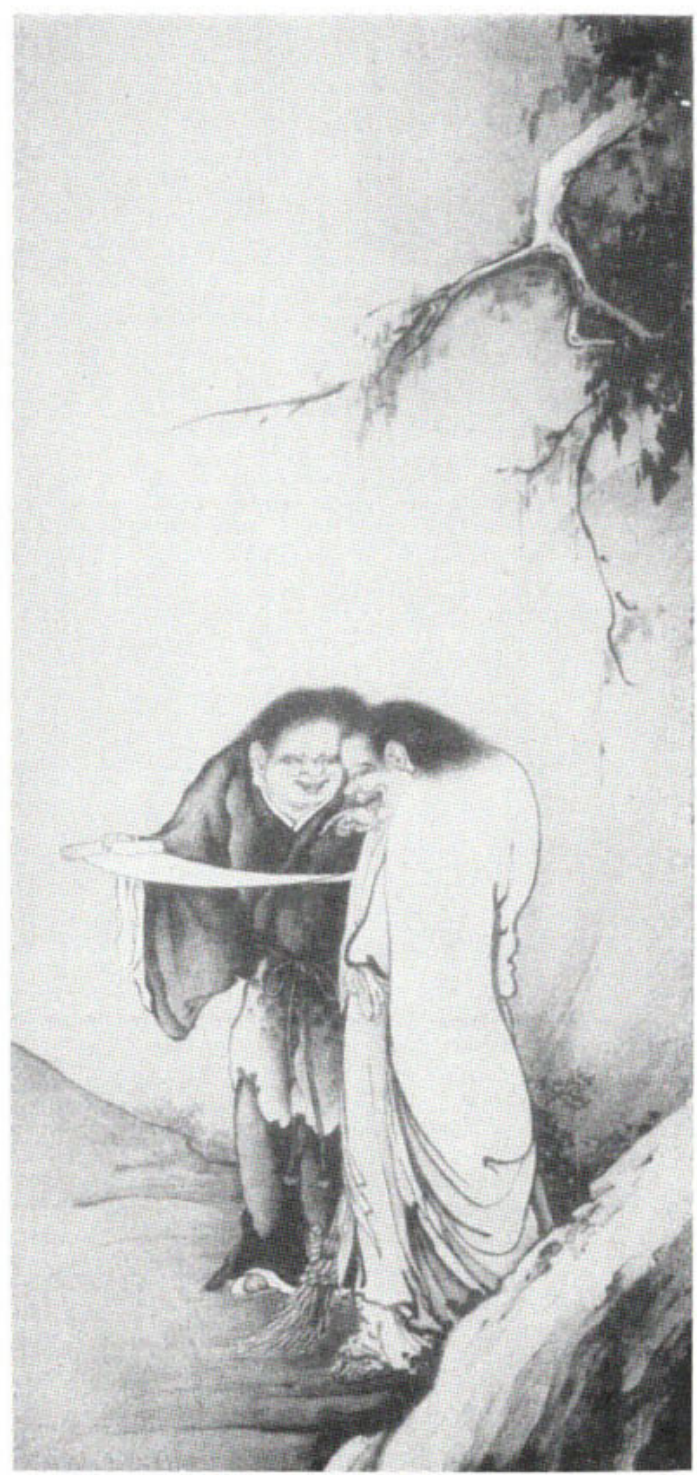

Zwei lustige Einsiedler

Gaho, 19. Fahrhundert 
JUNYU KITAYAMA

\section{WEST-ÖSTLICHE BEGEGNUNG}

JAPANS KULTUR UND TRADITION 


\section{DRITTE AUFLAGE}

Archiv-Nr. $346042 \cdot$ Gedruckt bei Walter de Gruyter \& Co

Berlin W 35, vormals G. F. Goschen'sche Verlagshandlung

7. Guttentag, Verlagsbuchhandlung - Georg Reimer - Karl

F. Trabner - Veit \& Comp - Printed in Germany 